\title{
THEORETICAL ANALYSIS OF THE FACTORS INFLUENCING MODERN TEACHERS' PROFESSIONAL SUCCESS
}

\author{
Tamara Skoryk
}

Candidate of Pedagogical Sciences, Associate Professor, Senior Lecturer at the Department of Art,

T. H. Shevchenko National University "Chernihiv Colehium”, Ukraine e-mail: tamskorik@ukr.net, orcid.org/0000-0002-1442-6024

\section{Nadiia Grytsyk}

Candidate of Pedagogical Sciences, Associate Professor,

Senior Lecturer at the Department of Foreign Languages

T. H. Shevchenko National University "Chernihiv Colehium”, Ukraine e-mail: Nadiela7027@gmail.com,orcid.org/0000-0001-7198-5327

\section{Summary}

The article examines the psychological and pedagogical principles of professional success in terms of coordination of individual and social requirements, professional and personal development of the teacher. The research issues are quite relevant in connection with current trends in education, which are aimed at achieving maximum quality in educational processes. From this point of view, the achievement of professional success by teachers is the key to qualitative changes in the education system. The article provides a theoretical analysis of the concept of "professional success" and defines the concept of "professional success of teachers" as a meta-category that is defined by complex indicators of professional competence, ability to teach, personal qualities and ability to self-realization in professional activities. It is determined that professional success is an integral characteristic of a teacher's activity, based on professional competence and pedagogical abilities, conducted by personal attitude to the profession and the ability to self-realization in it. On the basis of theoretical and empirical research the factors influencing formation of professional success of the teacher are defined. Theoretical analysis and survey of future teachers' ideas allowed to identify system-forming factors of professional success of teachers: professional competence, moral and ethical qualities of teachers, conscious choice of profession, emotional stability (formed emotional intelligence), self-realization in the profession. The study will provide an opportunity to develop a conceptual model of professional success of modern teachers, identify key criteria and indicators that determine the development of professional success of future teachers and professional teacher training at higher educational institutions.

Keywords: success, professional success of the teacher, personal qualities, professional competence, indicators of professional success.

DOI: https://doi.org/10.23856/3868

\section{The problem statement}

The scientific interest in the professional success of a teacher derives from its relevance to current trends in educational reform, which require teachers to be trained as highly qualified specialists, capable of carrying out professional activities in the context of the dynamism of educational institutions oriented to the development and self-development of students. There is 
an urgent need to study the psychological and pedagogical foundations of professional success in terms of reconciling individual and social requirements and the professional and personal development of the teacher, because the achievement of teachers' professional success is the key to a qualitative change in the education system as a whole. Such research requires a systematic analysis of the work of scientists in order to generalize it and create a modern conceptual model of the teacher's professional success. Due to the complexity and multicomponent nature of this concept, there is a need to identify and study the factors that determine professional success and influence its formation.

The National Education Development Strategy of Ukraine for the period 2012-2021, the Concept for the Development of Postgraduate Education in Ukraine, the Laws of Ukraine "On Education", “On General Secondary Education”, “On Higher Education” indicate that the teaching profession loses its status in society. There is a discrepancy between the social contract and the social role of the teacher. This has a negative impact on the professionalism of the teacher, resulting in a decline in the quality of all levels of education. From this point of view, it is necessary to ensure the growth of the prestige of the teaching profession in society through the training of teachers as high-level professionals and to create a stable motivation for professional growth. Professional achievement and success of teachers in the training process. The realization of the importance of the success of the teacher is conditioned by the increased requirements to professional training of the teacher. Thus, the educational environment of the higher educational institutions must develop the professional success orientation of future teachers.

\section{Research methodology}

General scientific and specifically scientific methods were used to achieve the objective: analysis, systematization and generalization of theoretical data, questionnaires, interviews, rating, analysis and synthesis of experimental data. The theoretical and methodological basis for studies of professional success is the position of various scientific schools and fields, which focus on the problem of establishing and supporting the success of a modern specialist: theory of professional development in domestic and foreign studies (A. Bodalev, S. Berezhna, L. Bozhovich, T. Kiseleva, L. Konovalova, N. Kuzmin, A. Markova, D. Jordan, D. Kreit, D. Suyper, L. Tyler, D. Tiedeman and others); positions of pedagogy of success (S. Frene, K. Ushinsky, A. Makarenko, V. Sukhomlinsky, S. Amonashvili, P. Blonsky); socio-psychological determinants of professional success (A. Bondarchuk, A. Brukhovetskaya, T. Dzhuba, A. Kurakov, A. Kononec, A. Moskatov, V. Ponomarev, Zh. Tymoshenko, etc.); theory of personal self-determination in professional activity (L. Antsiferov, V. Baimetov, S. Vasilkovsky, E. Klimov, I. Kobilyatsky, T. Kudryavtsev, A. Markov, N. Pryazhnikov, E. Rogov, V. Slashyoonin, M. Fitzla, M. Yarchenko, etc.); psychosemiotic approach to the definition of successful activity (E. Petrova, A. Radionova, A. Romanov, etc.); research of emotional intelligence as one of the determinants of success (R. Bar-On, D. Goulman, K. Saarni, J. Mayer, K. Petrides, E. Fernham, etc.).

The goal of the article is to carry out a theoretical analysis of the factors influencing morden teachers' professional success. To achieve the goal, we defined the following tasks:

- to analyze the essence of the concept of "professional success";

- to determine the factors of professional success of the morden teacher;

- on the basis of a survey of students (future teachers), highlight the most important factors influencing a teacher's professional success. 


\section{The results and discussion}

The concept of "professional success' is the subject of research of different sciences. The philosophical analysis of the category of success is based on two positions: from the point of view of a successful individual who aspires to self-realization, it means that the concept of "success" is close to the categories "life path", "sense", "existentialist"; another position the achievement of the person success is reduced to the formula "the goal is the satisfaction of the goal", that is, the successful is the one who has achieved the goal (Asmolov, 2007; Zinchenko, 1991).

Psychology analyses the perception of success in different research models: the conflict model (Z. Freud, K. Jung, E. Bern, etc.) the reconciliation model (J. Kelly, B. Skinner, etc.) the self-realization model (A. Adler, A. Maslow, F. Perls, etc.). These models offer different approaches to identify the category of success according to what is the driving force, the source of success.

From the pedagogical point of view, success can be the result of education. The pedagogy of success (K. Ushinsky, A. Makarenko, V. Suhommlinsky, S. Amonashvili, P. Blonsky) determine that success, which is a state of satisfaction with life, contributes to the further self-realization of the individual. This condition stimulates growth, can be related to both traditional activities and emotional, moral, spiritual maturity or the development of other aspects of the personality, which is also a life success (Romanovsky, 2011). Therefore, it is important to respect the principle of humanization in education, aimed at revealing the abilities and attributes of the individual through the creation of a comfortable learning environment.

Analyzing the concept of success, Yu. Nazar emphasizes that it combines objective measures of performance (productivity, product quality, etc.) and subjective measures - satisfaction with work, experience of inclusion, self-assessment of achievements as well as self-efficiency as a personal component of success (Nazar, 2013).

The analysis of the category "success" from the perspective of different approaches gives the opportunity to offer a holistic approach to model professional success of a teacher as a meta-construct of pedagogical activity. The professional success of a teacher is considered to be a meta-category, that is determined by complex indicators of professional competence, pedagogical ability, personal qualities and ability to self-fulfill in professional activity.

Professional success of a teacher is achieved by condition of personal and professional development up to the level of a professional with a steady motivation to self-development and able to effectively manage his emotional state and realizes his belonging to teaching profession (personal factor). Such awareness provides confidence in their professional abilities, helps teachers to adequately assess professional successes and failures, adjusts their own style of interaction with all participants in the educational process.

Thus, the professional success of a teacher is an integral characteristic of his activity, based on professional competence and pedagogical abilities, mediated by the personal attitude to the profession and the ability to realize in it. We can define the professional success of a teacher as the realization by the teacher of educational tasks at a reflexive level, accompanied by the state of personal satisfaction with the process and the results of his activity.

An important factor influencing the achievement of professional success is the personality characteristics of the subject and their type of professional activity. At the same time, a special set of personal qualities that determine professional success is determined and influence the formation of the personality and its self-realization. For a teacher, professional qualities are love for children, honesty, optimism, purpose, tolerance, perseverance, organization, openness, compassion and so on. These qualities are linked to the emotional and willful sphere and 
develop the educational success. Success studies highlight the personal traits of a successful person: active vitality, optimism, creativity, discovery, self-knowledge, self-expression, industriousness, flexibility, criticality, vision, etc. Among the most important personal factors contributing to professional realisation are personal efficiency, flexibility of behavior and dissatisfaction with personal activity. (Averyanova, 2017), deontological competence and identity as components of a professional successful personality of the future teacher (Barkasi etc., 2017).

The result of the studies shows that professional success is determined by a combination of both objective and subjective parameters. So, professional success depends on many factors, and at the personal level can be judged as important or insignificant. At the same time, they can be key to or hinder the development of teacher professionalism. In particular, one of the characteristics of a teacher's professional performance is that the results of a teacher's professional success are long-lasting in time (the student's assessment of a teacher's performance, in most cases, can be real only adulthood). This affects the teacher's internal assessment of the performance of his work, which can only be positive at a certain time.

As scientists point out that the perception of professional success is formed in the process of acquiring a profession, it is therefore important to create a sustainable awareness of the value of the profession and the orientation towards its success.

In order to identify indicators of professional success, we an attempted to define the perception of future teachers about the factors that determine it.

A survey conducted among the students of Primary School Education and Arts Faculty of T. H. Shevchenko National University "Chernihiv Colehium" (120 students of 3-4 courses participated in the survey), allowed us to make the following generalizations.

Among the personal factors that determine professional success, students cited:

- professional competence - $80.3 \%$;

- creativity and innovation in activity $-84 \%$;

- emotional stability (emotional intelligence) - 95.1\%;

- communication skills $-80.1 \%$;

- personal pedagogical style $-69.4 \%$;

- capacity for self-evaluation and self-improvement $-56 \%$;

- moral and ethical values and personal qualities $-81.5 \%$;

- charisma $-51.2 \%$;

- self-realization in the profession $-93.5 \%$.

Among the external factors that will determine the individual measure of their professional success, students chose:

- the children's behaviour - $63 \%$;

- the respect and authority among colleagues $-62.7 \%$;

- material reward $-59.2 \%$.

According to the students survey, the achievement of professional success is influenced by their informed choice of profession (76.2\%) and their own state of satisfaction with process and performance $(71.2 \%)$. It should be noted that $45.2 \%$ of respondents cited the importance of high wages as a criterion for success.

In assigning the most important personal qualities that contribute to the professional success of the teacher, the places were distributed as follows: 1 - love for children and profession, 2 - communicativeness, 3 - creativity, 4 - work efficiency and demanding, 5 - emotional stability, 6 - goodwill, 7 - optimism, 8 - empathy, 9 - humor, 10 - patience. At the same time, the students put the lack of balance and emotional stability at the top of their list of factors, the greatest obstacle to a teacher's professional success. 


\section{Conclusions and prospects for further research}

Our experimental work has made it possible to draw conclusions, according to students, the most important factors that determine the success of future professional activity are love for children and profession, creativity and innovation in activity, a state of internal satisfaction and comfort in professional activity. It has been established that for a teacher, students consider moral and ethical standards, internal qualities and emotional stability, on which professional competence should be built up as a priority (64.3\% of respondents). The following features of a teacher's professional success have been identified:

- the pedagogical activities are subjective: only a master teacher can build the right educational line of educational interaction with a specific pupil (there are no ready-made facilities for a specific case). Therefore, the factors of professional success are subjective and relevant to other subjective and objective factors;

- the teachers are guided by moral and ethical values, must be confident in their actions and must persevere in achieving the objective, so the personal qualities of the teacher become important;

- the leading role in the professional success of the teacher is his emotional intelligence, which ensures the emotional stability of the activity, the ability to understand the internal condition of both the students and teachers, and to choose an appropriate the means of interaction with them.

Thus, the teacher's success factors identified by us in the student survey process will allow the development of a conceptual model of teacher's professional success, which will help to improve the training of future teachers in the higher educational institutions. Further prospects for the study are the development and introduction of learning technologies that will aim to develop personal qualities and models of the teacher as a successful person capable to realize himself in professional pedagogical activity.

\section{References}

Averianova, A. (2017). Profesijnyj uspikh jak osnova samorealizaciji osobystosti. [Professional success as a basis for personal self-realization.] Scientific Journal of Mykolaiv V.O. Suhomlynsky National University. 1, 7-12. [in Ukrainian].

Asmolov, A. G. (2007). Psihologija lichnosti: kul'turno-istoricheskoe ponimanie razvitija cheloveka. [Personality psychology: cultural and historical understanding of human development (3rd ed).] Moscow, Publishing Center "Academy”, 528 p. [in Russian].

Barkasi V. V., Filipieva T. I., Biliuk O. H. (2017). Proektuvannja i rozvytok profesijno uspishnoji osobystosti $v$ umovakh osvitnjo-vykhovnogho seredovyshha universytetu [Design and development of a professional successful personality in the educational environment of the university.] Mykolaiv, Publishing Center "Illion". [in Ukrainian].

Nazar Yu. O. (2013). Definicija ponjattja uspishnosti profesijnoji dijaljnosti v socialjno-psykhologhichnomu konteksti [Definition of the concept of professional success in the socio-psychological context.] Retrieved from: http://www.sworld.com.ua/index.php/ru/conference/the-content-of-conferences/archives-of-individual-conferences/oct-2013.

Romanovsky, A. G. (2011). Pedaghoghika uspikhu: jiji sutnistj ta osnovni naprjamy vyvchennja. [Pedagogy of success: its essence and main directions of study.] Theory and practice of management of social systems. 2. 3-8. [in Ukrainian].

Zinchenko, V. P. (1991). Miry i struktura soznanija. [Worlds and structure of consciousness.] Issues of Psychology. 2. 15-36. [in Russian]. 